\title{
Planning that Works Outlined by an Educational Leadership Preparation Program in the United States that has Four Credentialing Agencies
}

\author{
Glenn L. Koonce, Ed.D. \\ Regent University \\ School of Education \\ 1000 Regent University Drive Adm Suite 243 \\ Virginia Beach, VA 23464, USA
}

\begin{abstract}
The landscape for program accountability in K-12 school leadership preparation can be daunting for even the most seasoned professor or higher education administrator. The rising demands in today's accountability-driven environment require individuals to have the knowledge and skills needed to provide evidence that all accrediting agencies and program approval agency standards are met or exceeded and that there is continuous improvement in program outcomes. For an educational leadership preparation program in the Southeastern portion of the United States, four accreditors/program approval agencies include the National Policy Board for Educational Administration (NCPEA), the Council for the Accreditation of Educator Preparation (CAEP), the Southern Association of Colleges and Schools Commission on Colleges (SACSCOC), and the Virginia Department of Education (VDOE). For those at the crossroads of assessment and evaluation responsible for establishing data gathering and data analysis, determining the best structures, supports, and approaches to advance student learning outcomes while fostering an improved school culture is a substantial undertaking.
\end{abstract}

Keywords: Educational Leadership, higher education, accountability, accreditation, program approval, continuous improvement

The objective of this study is to address improvement in university educational leadership (principal) preparation programs through the process of accreditation, program approval, continuous improvement, and to "enrich international conversations and build a global discourse in educational leadership" (Murakami-Ramalho and Barnett, 2008, p.1). Leadership is essential, and how school leaders are prepared both in the United States and internationally is critical to the success of schools and student achievement in those schools.

Leadership is second only to classroom instruction among all school-related factors that contribute to individual student achievement. While there can be successful teachers in failing schools, there are no effective schools without effective school leaders. As a result, school leadership is the key to closing achievement gaps and increasing student performance in all subjects across all grade levels (National Association of Secondary School Principals, 2013, p. 3).

There is currently a shortage in the number of principals for schools in the United States and the number of principal candidates in university preparation programs. It is projected that the need for school principals, at all levels, in the next ten years will grow 4 percent (Bureau of Labor Statistics, U.S. Department of Labor, 2019). Table 1 provides quick facts about elementary, middle, and high school principals from the United States in 2018.

Table 1

\begin{tabular}{|l|l|}
\hline $\begin{array}{l}\text { Quick Facts: Elementary, Middle, and High School Principals } \\
\text { 2018 Median Pay }\end{array}$ & $\$ 95,310$ per year \\
\hline Typical Entry-Level Education & Master's degree \\
\hline Work Experience in a Related Occupation & Five years or more \\
\hline On-the-job Training & None \\
\hline Number of Jobs, 2018 & 275,400 \\
\hline Job Outlook, 2018-28 & $4 \%$ (As fast as average) \\
\hline Employment Change, 2018-28 & 11,200 \\
\hline
\end{tabular}

Research from the Institute of Education Statistics (2016), shows that a third of principals do not continue in their position after three years. Retirement, transfer, or new opportunities are cited as reasons why principals leave, but the looming issue is the lack of qualified candidates to replace them. 
As a result, many school districts across the country report principal vacancies and a severe lack of qualified applicants to replace them. "Costs to recruit, hire, prepare, mentor, and continue training principals can cost school districts between $\$ 36,850$ and $\$ 303,000 "$ (p. 1). The impact of university educational leadership preparation programs is a real one as the literature continues to note weak programs lead to weak candidates.

\section{International Perspective}

The principal shortage figures are not dissimilar with the percentages found in other countries. A decade ago, Alan Winwood, a Lead Leadership Tutor with the United Kingdom's Fast Track Teacher Program stated, " 30 to $40 \%$ of our principals and vice-principals are going to retire in the next 5 to 6 years, and we don't have people at the moment who are willing and able to fill the gap" (McNeal, 2008, p. 20).

The Organisation for Economic Cooperation and Development (OECD) (2019) Teaching and Learning International Survey (TALIS) is an international, large-scale survey of teachers, school leaders, and the learning environment in schools. This survey presents findings based on the reports of lower secondary teachers and their school leaders in mainstream public and private schools. In England (U.K.), principals are, on average, 50 years old, which is lower than the average age of principals across OECD countries and economies participating in TALIS. Furthermore, $6 \%$ of principals in England (U.K.) are aged 60 and above, compared to $20 \%$ on average across the OECD (2019). The shortage gaps emphasize the need for quality school leaders (principals) in the United States.

With the shortages in qualified school leaders and criticisms of educational leadership preparation programs, the focus of this article is directed to program planning and program quality through the requirements of credentialing agencies for an educational leadership preparation program in the Eastern Region of the United States. These credentialing agencies provide the accountability measures for the program: 1) National Policy Board for Educational Administration (NPBEA) Professional Standards for Educational Leaders PSEL) and National Leadership Preparation (NELP) standards; 2) national accreditation from the Council for the Accreditation of Educator Preparation (CAEP) Standards for Advanced Programs; 3) regional accreditation from the Southern Association of Colleges and Schools Council on Colleges (SACSCOC); and 4) state accreditation and program approval from the Virginia Department of Education (VDOE). There is also an intent, in this article, to connect with educational leadership accountability (credentialing) from an international perspective.

The Paris-based OECD released the results of a study in April 2008 (Olson, 2008) titled Improving School Leadership: Policy and Practice at the Learning in the 21st Century: Research, Innovation, and Policy conference. The conference was held in Copenhagen, sponsored by OECD and the Danish Ministry of Education. The study called for better professional development for current school leaders and better preparation for future school leaders. The rising demands in an accountability-driven environment required individuals to have the knowledge and skills needed to run a learning-centered school. "Ensuring that principals and those involved in leadership receive adequate training and preparation to develop the right skills is crucial for effective leadership," the report states (Olsen, p. 1). Preparation is the first part of a continuum of training and support to address improvement in school leadership around the world. Education Week (Olsen, 2008) reported that a lack of school leadership was a global problem and cited the OECD study.

A decade later, in the OECD (2018) report, The Future of Education and Skills 2030, 22 countries have come together with the aim of the project to help countries find answers to two far-reaching questions: 1) "What knowledge, skills, attitudes, and values will today's students need to thrive and shape their world?" and 2) "How can instructional systems develop these knowledge, skills, attitudes, and values effectively" (p. 2). The framework was finalized in 2018, and the current emphasis is on exploring the "translation of the framework into pedagogy, assessment, and the design of an instructional system" (p.2). The primary focus moving forward is fivefold:

1) Shift the focus of students from 'more hours for learning' to 'quality learning time;'

2) Curricula reforms suffer from time lags between recognition, decision making, implementation, and impact. The gap between the intent of the curriculum and learning outcome is generally too wide;

3) Content must be of high quality if students are to engage in learning and acquire deeper understanding;

4) Curricula should ensure equity while innovating; all students, not just a select few, must benefit from social, economic and technological changes; and

5) Careful planning and alignment are critically important in the effective implementation of reforms. In response to these challenges, working group members and partners are co-creating 'design principles' for changes in curricula and education systems that will be relevant in different countries over time (p. 6).

Principals will be those leaders responsible for assuring the five foci of the OECD reforms are accomplished in every school in each of the 22 nations moving forward with this high-quality plan. For success to occur in these reforms, school leadership (principal) preparation programs in the OECD countries must continue to improve. 
The four credentialing agencies listed earlier provide the evidence needed to assure a quality program and continuous improvement. See Table 2 for a list of the 22 OECD countries and their populations (World Population Review (2019, p. 3).

Table 2 OECD Countries 2019

\begin{tabular}{|l|l|l|}
\hline Country & Year of Accession & Population 2019 \\
\hline Australia & & \\
\hline Austria & 1971 & $25,203,198$ \\
\hline Belgium & 1961 & $8,955,102$ \\
\hline Canada & 1961 & $11,539,328$ \\
\hline Chile & 1961 & $37,411,047$ \\
\hline Czech Republic & 2010 & $18,952,038$ \\
\hline Denmark & 1995 & $10,689,209$ \\
\hline Estonia & 1961 & $5,771,876$ \\
\hline Finland & 2010 & $1,325,648$ \\
\hline France & 1969 & $5,532,156$ \\
\hline Germany & 1961 & $65,129,728$ \\
\hline Greece & 1961 & $83,517,045$ \\
\hline Hungary & 1961 & $10,473,455$ \\
\hline Iceland & 1996 & $9,684,679$ \\
\hline Ireland & 1961 & 339,031 \\
\hline Israel & 1961 & $4,882,495$ \\
\hline Italy & 2010 & $8,519,377$ \\
\hline Japan & 1962 & $60,550,075$ \\
\hline Latvia & 1964 & $126,860,301$ \\
\hline Lithuania & 2016 & $1,906,743$ \\
\hline Luxembourg & 2018 & $2,759,627$ \\
\hline Mexico & 1961 & 615,729 \\
\hline Netherlands & 1994 & $127,575,529$ \\
\hline New Zealand & 1961 & $17,097,130$ \\
\hline Norway & 1973 & $4,783,063$ \\
\hline Poland & 1961 & $5,378,857$ \\
\hline Portugal & 1996 & $37,887,768$ \\
\hline Slovenia & 1961 & $10,226,187$ \\
\hline Spain & 2010 & $2,078,654$ \\
\hline Sweden & 1961 & $46,736,776$ \\
\hline Switzerland & 1961 & $10,036,379$ \\
\hline Turkey & 1961 & $8,591,365$ \\
\hline United Kingdom & 1961 & $83,429,615$ \\
\hline United States & 1961 & $67,530,172$ \\
\hline & 1961 & $329,064,917$ \\
\hline & & \\
\hline & & \\
\hline
\end{tabular}

\section{Accreditation}

As noted earlier, there has been sharp criticism facing university leadership preparation programs that they have failed to prepare school leaders adequately. A decade ago, one dilemma being faced in the United States was the fact that there were two fundamentally different national accrediting agencies for school leadership preparation programs; and second, accreditation was seen as a means to improve programs by designing a culture of evidence (Miller, Payne, Dwyer, Stickler, \& Alexiou, 2008). The dilemma was founded in the fact that there existed two federally recognized accreditors for leadership preparation: the National Council for Accreditation of Teacher Education (NCATE, operating since 1954) and the Teacher Education Accreditation Council (TEAC, operating since 1997). There were essential differences philosophical, structural, and procedural between the two organizations leading to very differing planning processes in preparing for the self-study, audit, and accreditation decisions. Educational leadership preparation programs decided which accreditation agency they would use, thus the process that accrediting agency required.

Much has occurred in the growth of college and university accreditation processes that have impacted the many challenges facing teacher and leadership preparation programs. These preparation programs prepare teachers and school leaders for licensure and professional positions in United States schools. Why are there two national accrediting agencies for teacher and school leadership preparation? 
In a book edited by Driscoll and Noriega (2006), accurately identifies for a growing number in the field, why there are differences between NCATE and TEAC. In the opinion of the researcher, this article could not have been written fifteen years ago - it would not have fit in the scene of higher education, would not have made sense to our colleagues, and it probably would have gathered dust on a shelf had anyone read it. In today's context of assessment and accreditation in higher education, we intend this book to be useful, offering strategies for the documentation process of accreditation (p. 1).

The quote is directly related to the quick growth into the age of accountability in higher education. Driscoll and Noriega present two important topics in their book. The first is the authentic descriptions they used at the California State University Monterey Bay (CSUMB) to undertake an accreditation self-study. The second was in their terms a "paradigm shift" (p. 1) in "assessment and in accreditation" (p. 2). They describe the assessment in higher education, in the past - "not so very long ago" (p. 2), as a "data gathering process assigned to an institutional office" (p. 2). Assessments for faculty did not involve the campus or research offices but occurred in the privacy of their classrooms. Here, faculty engaged in informal formative assessment (quizzes, question-and-answer sessions, homework assignments) or formal summative assessments (exams, final reports, projects). Seldom, if ever, did faculty use the central database. There was no connection, from the faculty to those who did access or stored the data. There was resistance to assessment on the part of the faculty in the fear that "assessment would be used to evaluate faculty and faculty's discomfort with their lack of expertise" (p. 2). Driscoll and Noriega's research points out that "some faculty view assessment as a threat to their academic freedom" (p. 2).

The faculty at CSUMB shifted their initial negative responses to assessment and "found value and used assessment to improve student learning and their own teaching" (p. 3). Why and how this shift occurred at CSUMB is discussed and described in twelve independent articles in the book. An interesting proposition for university faculty was made by Driscoll and Noriega, "both of those A-words (accreditation and assessment) along with a close relative, accountability, have not been popular on campuses. They have been misunderstood, considered suspect, and viewed as unconnected from the work of faculty and student learning" (p. 2). Can accountability be viewed as a third 'A-word.' The same A-word that accurately describes the accountability for student achievement K-12 school teachers, principals, and superintendents confront every day. This same pressure for accountability has made its way to the programs and professoriate that prepare teachers, principals, and superintendents. Accreditation is changing the accountability landscape in higher education in the United States.

The Council on Higher Education Accreditation (CHEA) appointed a Task Force in 2009, issuing a report that called for the creation of a unified system for national accreditation. NCATE and TEAC jointly appointed a group composed of representatives of the agencies to consider the issue. In a release, June 30, 2008, both organizations unanimously decided to recommend one accreditation system with "multiple pathways" to teacher education/school leadership education accreditation. The new national accreditor was named the Council for the Accreditation of Educator Preparation (CAEP). Table 3 displays the timeline in the transition from NCATE \& TEAC to CAEP (2019).

\section{Table 3 NCATE \& TEAC to CAEP Timeline}

\begin{tabular}{|l|l|}
\hline 2016: & $\begin{array}{l}\text { CAEP accreditation standards are fully implemented; NCATE and TEAC legacy } \\
\text { standards are no longer used for accreditation. }\end{array}$ \\
\hline 2014: & CAEP is recognized by CHEA. \\
\hline 2013: & $\begin{array}{l}\text { August 29, 2013 - The CAEP Board of Directors approve new accreditation standards. } \\
\text { July 1, 2013 - CAEP becomes fully operational as the sole accrediting body for educator } \\
\text { preparation providers. }\end{array}$ \\
\hline 2012: & $\begin{array}{l}\text { Commission on Standards and Performance Reporting convened to develop the next } \\
\text { generation of accreditation standards and performance measures for educator preparation. }\end{array}$ \\
\hline & $\begin{array}{l}\text { Ohio becomes the first state to sign a partnership agreement with CAEP as the new } \\
\text { educator preparation accrediting body. }\end{array}$ \\
\hline 2010: & Design Team report disseminated for public comment. \\
\hline & $\begin{array}{l}\text { Boards of NCATE and TEAC accept the Design Team report, which recommended the } \\
\text { formation of the new accrediting body: CAEP. }\end{array}$ \\
\hline First meeting of the CAEP Board of Directors. \\
\hline 1997: & $\begin{array}{l}\text { Teacher Education Accreditation Council (TEAC) founded, dedicated to improving } \\
\text { academic degree programs for professional educators, those who teach and lead in schools } \\
\text { pre-K through grade 12. }\end{array}$ \\
\hline $1954:$ & $\begin{array}{l}\text { National Council for Accreditation of Teacher Education (NCATE) founded as a non- } \\
\text { profit, non-governmental accrediting body. }\end{array}$ \\
\hline
\end{tabular}


Can national accreditation be an instrument for change in the way school leaders are prepared? Can national accreditation impact upon rigorous programs to develop highly qualified leaders who can help K-12 students reach their potential? What are the specific differences between the two accrediting agencies? What impact will the answers have on program improvement in the United States? What impact will all answers have on the noted lack of school leadership from a global perspective? Can CAEP become a model for other countries in their quest to improve their programs continuously?

"The landscape of national accreditation in higher education can be daunting for even the most seasoned professor or higher education administrator. Who will be taking the lead role? What does that role look like in the higher education culture? How would a professor teach, research, write, perform other duties - and accomplish the "accreditation thing" (Alstete, p. 1, 2004)? The answers to those questions are even more complicated because the new accrediting agency, CAEP, instituted standards and processes that are very different from NCATE \& TEAC.

"Accreditation happens when an outside, non-profit organization studies the programs offered at a college or university and after finding the school meets prescribed educational standards, grants a quality stamp of approval" (GuideToOnlineSchools, n.d., p.1). Most, if not all, professionals and professional organizations (e.g., architecture, engineering, medicine, law, business, psychology, and human services) have built their professions' reputation on being one that is accredited. "Accreditation can be seen as a sort of educational insurance" (GuideToOnlineSchools, n.d., p.1). Most students earning degrees would not attend a school that is not accredited. Accreditation is a way of knowing the education provided has met standards set by both the government and experts in the field of postsecondary education (Alstete, 2004).

A brief commentary to the rich past in the birth and growth of higher education accreditation provides insight into answering questions posed. Accreditation began as colleges grew, very slowly, after the civil war era. Not many people in the United States attended college in the late nineteenth century, and at the time college was "largely a proscribed doctrine based on an ancient course of study (Latin, Greek, Hebrew, logic, and natural philosophy) at institutions that were primarily religious in nature" (p. 6). For numerous reasons, the growth of colleges and universities, their diversity in purpose, and lack of administrative functions, such as admissions processes, led to a movement, around 1890, to accredit the institutions that met minimal standards. Regional associations of accreditation had been instituted in 1887 by the Middle States Association of Colleges and Schools, followed by the Southern Association of Colleges and Schools (SACS) and the North Central Association of Colleges and Schools (NCACS) in 1895. During the time, a major concern was deciding if a school was a secondary school or a college. The result was quick growth in minimal level standards to determine the differences. The Northwest Association of Schools and Colleges (NASC) was instituted in 1917 and, after some time, the Western Association of Schools and Colleges (WASC) in 1962. Today, there are2,618 accredited four-year colleges and universities, and most operate privately or as part of state governments (PENNGSE Graduate School, 2019).

The medical field became the first profession to establish national accreditation after a report on the need for common standards in the profession was published in 1910. For the field of education, the Federal Government instituted the practice of national accreditation in colleges and universities in the early 1960s "to demonstrate to the Federal government a basic level of quality in their institution" (National Association of Private and Independent Schools, n.d. p.1). There was also a need by the Feds to certify eligibility to receive Federal funds, which included Stafford loans, grants, and research monies. National accreditation applies only to postsecondary education, not for K-12 elementary and secondary schools.

"Europe is creating the model for world higher education through the Bologna Process with its clear indications of what paths through higher education look like and the skill and knowledge levels students need to obtain a degree" (EHEA, 2019, p. 7). The European Higher Education Area (EHEA, 2019) is a unique international collaboration on higher education. The result of the political will of 48 countries with different political, cultural, and academic traditions, which, step by step during the last twenty years, built an area implementing a standard set of commitments: structural reforms and shared tools. These 48 countries agree to adopt reforms on higher education based on common fundamental values- such as freedom of expression, autonomy for institutions, independent student unions, academic freedom, free movement of students and staff. Through this process, countries, institutions, and stakeholders of the European area continuously adapt their higher education systems making them more compatible and strengthening their quality assurance mechanisms. For all these countries, the main goal is to increase staff and students' mobility and to facilitate employability. This official website of EHEA provides both general information on this process and detailed information for experts (p.1).

Through the development of "qualification frameworks," the Bologna Process has created an initial set of student learning outcomes that are driving credit and curriculum reform. The 46 European countries involved are "giving meaning to what a student can do upon degree attainment" (p. 11).Although the work of Bologna reviewed was not specific to graduate-level educational leadership preparation programs, it certainly speaks to the rigor and speed in which the European higher education accountability culture is moving. 
It identifies reasons why institutional effectiveness in the U.S. may be playing catch-up as it loses its position as "the most trusted supplier" (p. 7) in the global higher education arena. The success of the Bologna Process comes through communities of practice that are formed through various working and advisory groups, which enables institutional cooperation and mobility between European and non-European countries. This has led to an attractiveness of European higher education to students and academics from other parts of the world and raises its global competitiveness (European Commission/EACEA/Eurydice, 2018).

The Europeans are not alone as new giants in the global higher education community grow and develop. India and China are expanding their ability to offer access to postsecondary education at home, and "they are not going to stop building anytime soon" (p. 7). Both countries are emphasizing evidence of student learning as a measure of accountability. It appears that internationally, accountability for student achievement is growing and that these countries are looking at the evidence university programs produce to measure their success. Accreditation is increasing as a means to track and approve these programs.

\section{Planning for Educational Leadership Preparation}

The critical link to educational planning in a culture of evidence is student success/student achievement through assessment of student learning outcomes. This connection is integral to the institution's mission. In turn, this critical focus becomes the cornerstone for institutional effectiveness and strategic planning. Thus, educational planning challenges are more pressing and difficult than ever, both in the U.S. and globally. "Making measurement of student learning an integral component of the institution and tying it to its institutional aspirations, colleges and universities make manifest their commitment to the core mission of student learning" (p. 18).

There is no doubt that new and or revised processes for accountability are directly connected with accreditation. Changes in U.S. educational leadership preparation programs have been made to reflect student outcomes instead of just inputs better. For K-12 student outcomes, the most critical evidence for accountability is not found in attaining the degree or even in achieving a school leadership position upon graduation.For graduates who have achieved a school leadership position, the question is, what evidence can be gathered from their success or lack of success in K-12 student achievement that can be attributed to their leadership preparation at their university. This one component of the educational leadership preparation problem and dilemma is vital for this paper and will be the concluding statement. Fullan (2003) states it best, the "moral imperative of school leadership is student achievement" (p. 1). A question to ponder is K-12 student achievement the only authentic piece of evidence and the remaining portions merely proxies? No matter what thoughts may come to mind, it is evident that the accountability placed on K-12 leaders in the field is moving to university professors and administrators.

Faculty members in school leadership preparation programs are feeling the impact of accountability as a result of recent or current national accreditation requirements. The effect on their feelings and possibly their dispositions may be compared to their distant cousins in the ability for K-12 student achievement in their schools and school districts. And this accountability includes another big A-word - All students. The term, All students, has no pretense; it is all-inclusive (race, ethnicity, gender, specials need, English language learners, etc.).

"Professional accreditation of preparation programs is the bedrock upon which all professional accreditation assures that those entering the respective field are suitably prepared to practice through mastery of a body of knowledge and pre-service practices in the profession" (NCATE' s Mission, 2008). TEAC agrees (2005), accreditation of undergraduate and graduate professional education programs assure the public about the quality of college and university programs.

The requirements of the four credentialing agencies, a listing of their standards and competencies, can be found at the organization's websites.

\section{Summary}

In summary, the new accountability environment in higher education for a university educational leadership preparation program in the southeastern part of the United States is mandated by standards and competencies from four credentialing agencies. It is wise for universities in the process of meeting accountability for their programs to review the literature and understand the requirements of any agency that accredits or provides program approval. The journey of an educational leadership faculty preparing for accreditation face many hurdles in understanding the accountability terrain and moving the process along. There are immeasurable revelations and successes in leading the faculty towards its accountability goals.

This article has addressed accountability through national standards, national and regional accreditation, and state program approval. The results produce a culture of evidence for submitting a self-study, matrix, or document for audit and approval. To separate the accreditation process from the planning process is not possible. What is possible is to delineate terms. Where accountability and accreditation are focused on the term culture of evidence, educational planning can be termed a culture of continuous improvement. This culture of continuous improvement is accomplished through strategic planning. 
Strategic planning provides a road map to show where the organization wants to go in the future and how to get there. Crucial components of the strategic planning process in colleges and universities begin with vision and mission but do not end with evaluation because future planning results from the evaluation and the cycle repeats itself continuously. Thus, a culture of continuous improvement is life-long. With-in the strategic plan are assessment and evaluation principles and practices that measure student learning outcomes. The results of these measurements and assessments are the performance indicators for quality assurance and quality improvement.

To conclude, accountability, national accreditation, and continuous improvement in educational leadership preparation programs are about many things. Let us never lose sight of the ultimate purpose that engenders the time and energies of those in the academy. The ultimate goal for attaining national accreditation and continuous improvement for a college or university educational leadership preparation program graduates' success is K-12 student achievement and closing the achievement gap.

\section{References}

Alstete, J. (2004). Accreditation matters: achieving academic recognition and renewal. San Francisco: Jossey Bass. Bureau of Labor Statistics, U.S. Department of Labor (2019). Occupational outlook handbook, elementary, middle, and high school principals. Retrieved from https://www.bls.gov/ooh/management/elementary-middle-andhigh-school-principals.htm

CAEP (2019). CAEP Standards for accreditation at the advanced level. Retrieved from http://caepnet.org/standards/standards-advanced-programs

Driscoll A. and Noriega, D. (2006). Taking ownership of accreditation: Assessment processes that promote institutional improvement and faculty engagement. Sterling, VA: Stylus Publishing, LLC.

European Commission/EACEA/Eurydice (2018). The European Higher education area in 2018: bologna process implementation report. Luxembourg: Publications Office of the European Union.

EHEA (2019). European high education area \& bologna process. Retrieved from http://ehea.info/

Fullan, M. (2003). The moral imperative of school leadership. Corwin Press, Thousand Oaks, CA.

GuideToOnlineSchools. (n.d.) What is accreditation? Retrieved from www.guidetoonlineschools.com on June 14, 2008.

Institute of Education Statistics. (2016). Trends in public and private school principal demographics and qualifications: 1987-88 to 2011-12. Washington, DC: U.S. Department of Education. Retrieved from http://nces.ed.gov/pubs2016/2016189.pdf

Miller, C., Payne, D., Dwyer, C., Stickler, L., and Alexiou, J. (2008). A culture of evidence: An evidence-centered approach to accountability for student learning outcomes. Educational Testing Service, N.J.

McNeal, L. (2008). An Interview with Alan Winwood. University Council for Education Administration Review, XLIX,2, 20.

Murakami-Ramalho, E. and Barnette, B. (2008). Globalizing conversations in educational leadership. University Council for Education Administration Review, XLIX,2, 1-4.

National Association of Private and Independent Schools. (n.d.). Accreditation news. Retrieved July 20, 2008, from www.napcis.org/AccreditationNewsW-04.html.

National Association of Secondary School Principals. (2013).Leadership Matters. Retrieved from https://www.naesp.org/sites/default/files/LeadershipMatters.pdf

NCATE's Mission. (2008). Retrieved July 19, 2008, from www.ncate.org/documents/NCATEmission

OECD (2018). The future of education and skills. Retrieved from https://www.oecd.org/education/2030/E2030\%20Position\%20Paper\%20(05.04.2018).pdf

OECD (2019), TALIS 2018 Results (Volume I): Teachersand School Leaders as Lifelong Learners, TALIS. OECD Publishing, Paris. Retrieved from https://doi.org/10.1787/1d0bc92a-en

Olson, L. (2008). Lack of school leadership seen as a global problem: OECD study finds too few candidates at a time when the roles have expanded. Education Week. April 16, p. 1. Retrieved from https://www.edweek.org/ew/articles/2008/04/16/33oecd.h27.html

PENNGSE Graduate School. (20019). How many colleges are in the U.S.? Retrieved from https://www.urbanedjournal.org/education/how-many-colleges-are-in-the-us-numbers-of-colleges-andeducational-institutions

TEAC, Teacher Education Accreditation Council. (2005). Guide to accreditation. Washington, D.C.

World Population Review (2019). OECD Countries, 2019. Retrieved from http://worldpopulationreview.com/countries/oecd-countries/ 